\title{
Coronavirus-2019 Disease (COVID-19) in Children
}

\section{Çocuklarda Coronavirus Hastalığı 2019 (COVID-19)}

\section{Fahri OVALI $\odot$}

Ethics Committee Approval: Not Applicable.

Conflict of interest: The authors of this article is one of the Editorial Board Members of this journal and was excluded from all evaluation steps

Funding: None.

Informed Consent: Not Applicable.
Cite as: Ovali F. Coronavirus-2019 disease (COVID-19) in children. Medeni Med J. 2020;35:242-52.

\begin{abstract}
COVID-19 disease affects all ages, but severe cases of the disease and mortality are very rarely seen among children. In most cases, they acquire the virus from their parents or from an another infected person. The exact reasons why the disease has a milder course in children is unknown but high numbers of Angiotensin Converting Enzyme-2 (ACE2) receptors, underdeveloped immune responses, cross-reaction with other viruses, protective effect of fetal hemoglobin and fewer outdoor activities as well as journeys, and nonexposure to air pollution, and smoking. Although many cases are asymptomatic, they can still shed the virus. Materno-fetal vertical transmission has not been shown so far. In symptomatic cases, clinical findings include fever and respiratory symptoms, followed by diarrhea and vomiting. There are signs indicating a possible association between Kawasaki disease and COVID-19. Clinical findings and diagnostic procedures in newborns, and older children are similar. Supportive therapy is essential and antiviral agents are not required in most cases. During cytokine storm, anti-inflammatory treatments may be tried. There is no evidence for transmission through breastmilk; therefore infected mothers should breastfeed their infants by taking all precautions. Routine immunizations of children should not be deferred during COVID-19 outbreak period. Psychological support for children who need to stay at home and for healthcare personnel should be provided.
\end{abstract}

Keywords: Coronavirus 2019 disease, COVID-19, SARS-CoV-2, children, newborn

öz

COVID-19, tüm yaş gruplarını etkiler ancak çocuklarda ağır vakalar genellikle azdır ve mortalite çok düşüktür. Birçok durumda çocuklar hastalığı ebeveynlerinden veya yakın çevresinden alırlar. Çocuklarda hastalığın neden hafif geçtiği tam olarak bilinmemektedir ancak ACE2 reseptörlerinin fazla oluşu, immün sistemlerinin tam olarak gelişmemiş olması, sık görülen diğer viral ajanlarla çapraz reaksiyon olması, fetal hemoglobinin koruyucu olması, ev dışında daha az zaman geçirmeleri ve daha az seyahat etmeleri, sigara ve hava kirliliğine maruz kalmamaları etkili olabilir. Birçok vaka asemptomatik olmasına rağmen virusü etrafa bulaştırabilirler. Anneden fetusa vertikal geçis gösterilememiștir. Semptomatik hastalarda ateș ve solunum sistemi bulgularını ishal ve kusma izler. COVID-19 ile Kawasaki hastalığı arasında ilişki olabileceğini gösteren bulgular vardır. Yenidoğanlardaki bulgular ve tanısal testler büyük çocuklardakine benzerdir. Çocuklardaki esas tedavi şekli destek tedavisidir ve birçok hastada antiviral tedaviye gerek yoktur. Sitokin firtınasının geliștiği durumlarda anti-inflamatuar tedaviler yapılabilir. Anne sütünde virus gösterilememiştir, bu yüzden anneler tüm önlemleri aldıktan sonra bebeklerini emzirmelidir. Bu dönemde çocukların rutin aşılanması ihmal edilmemelidir. Evde kalmak zorunda kalan çocuklara ve sağlık personeline psikolojik destek yapılmalıdır.

Anahtar kelimeler: Coronavirüs 2019 hastalı̆̆ı, COVID-19, SARS-CoV-2, çocuk, yenidoğan
Received: 20 May 2020

Accepted: 18 July 2020

Online First: 30 September 2020

\section{Corresponding Author:}

F. Ovali

ORCID: 0000-0002-9717-313X

Istanbul Medeniyet University Faculty of Medicine, Department of Pediatrics, Division of Neonatology, Istanbul, Turkey

fovali@yahoo.com 


\section{INTRODUCTION}

Coronaviruses are single stranded RNA viruses which cause a number of infections in animals and humans. Since they are RNA viruses, genetic mutations and recombinations are frequent. SARSCoV-2 which was first seen in Wuhan, China in December 2019 is a beta-coronavirus which belongs to the same family with the previous Severe Acute Respiratory Syndrome (SARS) virus and Middle East Respiratory Syndrome (MERS) virus. The disease which occurs with SARS-CoV-2 is called as COVID-19'.

COVID-19 infection affects almost all ages. The incubation period is usually between 5-6 days but may reach up to 14 days $^{2}$. As of May 20, 2020 there were over 5000000 proven cases globally, and more than 325000 deaths $^{3}$.

\section{EPIDEMIOLOGY OF COVID-19 IN CHILDREN}

SARS-CoV-2 infects the entire population. Although children comprise almost $20-25 \%$ of population in different countries, infected children comprise various proportions of the whole population as indicated in China (2\%), in the USA $(1.7 \%)$, in Spain $(0.8 \%)$, in Italy $(1.2 \%)$, and in Turkey $(1 \%)^{1,4-7}$. In a study which reported 171 pediatric cases with covid-19 infection, 31 (18.1\%) were under 1 year of age, only 39.2\% were females and $64.9 \%$ had pneumonia and $41,5 \%$ had fever $^{8}$. As of April 2, 2020, there were 2572 pediatric cases of covid-19 infection in the USA. Three hundred and ninety-eight of these children (15\%) were below 1 year old. There were 3 fatalities among the pediatric cases ${ }^{6}$.

Children may acquire the virus through droplets, direct contact, aerosols or fecal-oral route. However, there is no evidence so far showing the spread of virus from feces to a person. Current data suggest that $56 \%$ of children with SARSCoV-2 infection have evidence of transmission through family contact ${ }^{9}$. The youngest of the con- firmed cases was 30 hours of age and the oldest patient was 18 years old ${ }^{10}$.

Multiple reports suggest that the disease is milder in children and the mortality rate is much lower than that in adults, but they may be contagious. Asymptomatic, mild, and moderate cases account for $98 \%$ of childhood cases ${ }^{11}$. Severely ill cases are defined as those with central cyanosis and pneumonia, and critically ill cases are those that develop acute respiratory distress syndrome necessitating mechanical ventilation. Even if they are asymptomatic, they can be vectors and they can shed the virus.

\section{WHY IS THE DISEASE MILD IN CHILDREN?}

The reasons why SARS-CoV-2 infections in children are mild is not clear. There are variety of reasons for the differences between adults and children.

\section{Role of Angiotensin-converting enzyme 2 (ACE2)}

SARS-CoV-2 enters the cell by using ACE2 receptors. These receptors are present in the mucosal cells (lips, eyelids, nasal cavities), lung epithelial cells, lung parenchyma, intestine, kidney, and blood vessels as well as on monocytes, neutrophils and lymphocytes. Binding of the SARSCoV-2 spike protein to ACE2 downmodulates ACE2 expression which results in severe lung damage. ACE2 alters the proinflammatory reticuloendothelial system activity to anti-inflammatory response. On the other hand, ACE2 is protective against severe lung injury In Respiratory Syncythial Virus (RSV) infections. Intracellular response induced by ACE2 in the lung may be lower than that of adults ${ }^{12}$. In acute lung failure, ACE2 seems to be protective. In general, in children the level of ACE2 is higher than those in adults, and children with COVID-19 have generally mild symptoms. ACE is able to pass through the placenta, thus rendering the mother to transfer her immunity to her infant ${ }^{13}$. In children, soluble ACE2 can 
facilitate overcoming the virus. Therefore, they fight against the virus more steadily but also they become unidentified carriers. Levels of ACE2 may provide insight for the prognosis ${ }^{1}$.

\section{Inflammatory responses}

The immune systems of children and adults are different as well as immune systems of infants, preschool children and teenagers. In the final stage of severe COVID-19 infection, lethal massive proinflammatory response (i.e. cytokine storm) appears. It may be associated with hemophagocytosis or macrophage activation syndrome because there is increased ferritin levels, decreased platelet and erythrocyte counts, sedimentation rates ${ }^{11}$. However, this response is underdeveloped in children which is reflected in the fact that respiratory symptoms including shortness of breath or cough are encountered less frequently than adults. In the adult population, development of lymphopenia during the course of disease may facilitate the virus to proliferate and spread. On the other hand, the number of leukocytes and lymphocytes are generally normal in children, possibly due to incomplete natural immunity of children ${ }^{11}$.

T cells are responsible for clearing viruses. CD4+ $T$ cells stimulate B-cells to produce antibodies against SARS-CoV-2. In children, efficient T cells may respond better to SARS-CoV-2. As the children get older, continuous stimulation with antigens and thymic involution lead to a change in $\mathrm{T}$ cell subset levels. This change is accompanied by the loss of expression of co-stimulatory molecules such as CD27 and CD28, leading to increased susceptibility to infections ${ }^{14}$.

Several animal studies imply that antibodies against SARS-CoV-2 may be conductive to lung injury ${ }^{15}$. Higher antibody levels against SARSCoV-2 are correlated with elevated CRP and lymphopenia. Since they may have acquired various infections before, children may develop more favorable immunoglobulin isotypes or have im- proved antibody response against SARS-CoV-2 ${ }^{16}$. Secondary bacterial infection(s) may develop, which further complicates the disease and increases mortality. There is no evidence so far regarding the severity of infection in immunocompromised children.

\section{Cross-immunity with other agents}

Simultaneous presence of other viruses including adenoviruses, enteroviruses, rhinoviruses, influenza viruses, and coronaviruses in the upper airways and lungs of children, which is not rare, may slow down the growth of SARS-CoV-2 by competition or viral interaction ${ }^{1}$.

\section{Fetal hemoglobin}

SARS-CoV-2 virus proteins show affinity to the heme group on the $\beta$ chain of hemoglobin and dissociate iron leading to porphyrin formation. Thus, hemoglobin level is decreased leading to hypoxia which inhibits the normal metabolic pathway of heme. The majority of hemoglobin in the newborns is fetal hemoglobin (HbF) which consist of alpha and gamma chains; hence HBF may be protective against SARS-CoV-2 ${ }^{1}$.

\section{Environmental factors}

Children are generally overprotected by parents and they have fewer outdoor activites and travel less, rendering them less likely to get into contact with an infected person. Less exposure to smoke and air pollution may render children to lower prevalence of SARS-CoV-2 infection in children albeit with limited data. Ambient air temperature, nutritional status of children, rate of contact with sick adults may be effective, however evidence is pending. Hospital environment is also important; aerosolised medications, intubation, and endoscopy centers may be potential foci for the transmission of the virus ${ }^{1}$.

\section{CHILDREN AS CARRIERS}

Not only symptomatic but also asymptomatic individuals may carry and spread the virus, notwith- 
standing children. In the USA, $27 \%$ of pediatric cases which had positive PCR results were asymptomatic, compared to only $7 \%$ of adults. Similarly in China, among exposed children, 28\% were asymptomatic carriers ${ }^{17,18}$. Children who are infected with SARS-CoV-2 may have upper respiratory tract involvement. Continuous shedding with nasal secretions and stool may have considerable results for community spread in kindergartens, schools, and home ${ }^{19}$. These mildly symptomatic or asymptomatic children may play an important role in the spread of the virus. Milder forms of the disease in children should not be underestimated. Preventive measures should be taken just like as adults. Social distancing should be practiced especially with children, elderly people or with people with chronic medical conditions. It can be argued that due to a lower viral load in children, disease transmission may prime the child to develop a memorized immune response and limit the progression of the disease. Therefore, children may be effective in developing herd immunity.

\section{MATERNO-FETAL VERTICAL TRANSMISSION}

Transmission of SARS-CoV-2 virus from the infected pregnant woman to her fetus is still unclear. Viremia is seen in only $1 \%$ of COVID-19 cases, which suggests that placental and fetal spread may be extremely rare $^{20}$. In case of viremia, the disease is more severe. The ACE2 receptor is expressed abundantly in the placenta, which has a similar receptor binding domain structure of SARS-CoV-2. Polymerase Chain Reaction (PCR) findings of the placenta and amniotic fluid of suspected fetuses have been negative until now ${ }^{1}$. Positivity for specific $\operatorname{Ig} M$ is not a definitive evidence of intrauterine infection. Some studies have reported a higher rate of preterm birth among infected mothers ${ }^{21}$.

During vaginal delivery, viral transmission is possible by direct contamination of the infant by vaginal secretions, and by the droplets of the infected mother, if no personal protective equipment (PPE) is used $^{22,23}$.
Until now, all the pregnant women who have been infected have been in their third trimesters, therefore it is not possible to have a clear idea on the transmission rates in the first or second trimesters. Furthermore, since fever is one of the major signs of SARS-CoV-2 infection, it may be speculated that high fever in the first trimester may lead to increased risk of congenital anomalies or miscarriage during the organogenesis period. It may be expected that more information on the transmission dynamics of the SARS-CoV-2 during the first and second trimesters may be available in the future.

\section{CLINICAL MANIFESTATIONS IN CHILDREN}

In the study of Lu et al. ${ }^{24}$, the median age of diagnosed children was 6.7 years, with a slight preponderence for boys. In another study of 25 infected children, the median age was 3 years, 14 of them were males and 21 of them had a contact history. Incubation period in children is usually between 2-10 days ${ }^{25}$. Common symptoms include dry cough, fever, myalgia and fatigue. Some patients may have few upper respiratory symptoms such as nasal congestion or runny nose and some children may have gastrointestinal symptoms such as abdominal pain, abdominal discomfort, nausea, vomiting, and diarrhea. Fever persists mostly 1 - 2 days (maximum 8 days). Chest CT findings revealed bilateral involvement in almost half of the cases and unilateral involvement in $20 \%$ of cases $^{26}$. In another large-scale study from Spain, most frequent clinical findings were upper respiratory tract symptoms, followed by viral pneumonia, fever, gastroenteritis, and vomiting. Four children out of 365 required mechanical ventilation. There was no mortality ${ }^{5}$.

Children with COVID-19 may present in 5 types: Asymptomatic infection, mild, moderate, severe, and critically severe infection. The prevalence rates of severe or critical disease were $10.6 \%$ in children below 1 year; $7.3 \%$ between 1 -5 years, and $4.2 \%$ between $1-5$ years, decreasing to $3 \%$ 
between 16-17 years ${ }^{15}$. In the USA, hospitalization rate was $1.6-2.5 \%$, with no child requiring intensive care ${ }^{27}$. Children younger than 1 year have the highest percentage of hospitalizations among pediatric patients ${ }^{28}$. In Turkey, $50.4 \%$ of infected children had mild disease, and $0.8 \%$ had severe disesase. Intensive care was needed in $4.27 \%$ of children, and $80 \%$ of them were under 1 year of age ${ }^{7}$. Among 171 infected children, only 3 of them with co-morbidities required mechanical ventilation. There were few asymptomatic children with pulmonary findings ${ }^{8}$. Most of the deaths and severe diseases reported in children have occured in those with comorbidities including hydronephrosis, leukemia, and diabetes. Majority of the children recover within 1-2 weeks after symptoms appear ${ }^{29}$. The overall death rate for SARS-CoV-2 infection is around $2.2 \%$, but it is extremely rare in children ${ }^{30}$. Anosmia is a rare manifestation of the disease which resolves within 7-10 days.

Recently, there have been some reports linking COVID-19 to Kawasaki disease (KD). The etiology of Kawasaki disease remains unknown but there is substantial data suggesting a viral etiology $^{31}$. Many viruses are associated with Kawasaki disease, including coronavirus. Verdoni et al. ${ }^{32}$ reported 10 cases of $K D$, at the peak of the pandemic in Italy, the incidence was 30-fold higher than observed in the previous 5 years. Two of 10 children had a positive PCR test for SARS-CoV-2, whereas the remaining 8 children had a positive serology for SARS-CoV-2. A 6-month- old female infant with classical findings for KD, also tested positive for COVID-1933. She did not have respiratory symptoms, including cough, congestion or rhinorrhea. Since KD is a multisystem inflammatory disease, and cytokine storm syndrome at the last stage of COVID-19 has a multisystem involvement, a common pathophysiologic pathway may be considered ${ }^{34}$. In patients presenting with persistent fever, manifestations of KD should be sought.

\section{CLINICAL MANIFESTATIONS IN THE NEWBORNS}

The most prevalent characteristic of COVID-19 disease in children is a history of contact with a confirmed case of COVID-19 (commonly the mother) or travel history to an infectious area. The newborn may be asymptomatic. Diagnosis is confirmed by real-time PCR in the respiratory tract swabs ${ }^{1}$.

The clinical findings in the newborns are nonspecific. The infant may have or have not fever. Some of them may have respiratory symptoms such as cough, tachypnea, apnea, grunting, nasal flaring, tachycardia, notwithstanding lethargy, vomiting, diarrhea, and abdominal distention ${ }^{35,36}$. The infant is regarded as positive if any of the following findings is present: a) positive PCR test result for SARS-CoV-2 in respiratory tract or blood samples, b) high homology of SARS-CoV-2 viral gene sequences of the samples from the respiratory tract or blood to the COVID-19 sequence. The findings should be interpreted more cautiously In severe cases and in cases with immune deficiency, congenital heart disease, bronchopulmonary dysplasia, respiratory tract anomalies, severe malnutrition or anemia ${ }^{1}$.

\section{DIAGNOSTIC PROCEDURES}

Since most of the cases are asymptomatic or mildly symptomatic, majority of children do not need diagnostic investigations. At first, history of exposure to a suspected patient within the last 2 weeks should be investigated. Personal history should include the presence of fever, respiratory, and gastrointestinal symptoms. Laboratory findings are generally nonspecific. Leukocyte counts may be within normal limits or elevated, and lymphocyte counts may be decreased. Platelet counts may be decreased, accompanied by mild elevations of creatine kinase, alkaline phosphatase, alanine aminotransferase, aspartate aminotransferase, and lactate dehydrogenase. Some cases are associated with increased procalcitonin and IL-6 levels ${ }^{1}$. 
The virus may be isolated from the upper or lower respiratory tract, blood or feces. The viral load in patients with mild disease is lower compared to those having severe infection. Increased viral load is also associated with higher age. Lung screening should be performed to detect any parenchymal infiltration. Ground-glass opacity is seen in almost one third of children with confirmed infection ${ }^{24}$. Lung CT should be obtained only in suspected cases since substantial amount of radiation during $\mathrm{CT}$ may have some detrimental effects.

\section{MANAGEMENT OF COVID-19 IN CHILDREN}

Supportive treatment including oxygen therapy, fluid and electrolyte management, nutritional support, maintaining hemodynamic stability of the infant, management of fever, and antibiotics for bacterial superinfections is essential, notwithstanding personal hygiene and infection control measures.

Noninvasive methods should be preferred, but one should bear in mind that these procedures may cause aerosolization, and specific precautions should be taken. Conventional mechanical ventilation, high frequency ventilation or nitric oxide therapies may be needed in severe cases. In most severe cases, continuous renal replacement therapy or extracorporeal membrane oxygenation (ECMO) may help.

Medical treatments in older children and in children with severe pulmonary findings may include, hydroxychloroquine, azithromycin, and lopinavir + ritonavir. Hydroxychloroquine is an anti-malarial drug, which has been used in autoimmune diseases successfully. Hydroxychloroquine increases the endosomal $\mathrm{pH}$ and inhibits virus-cell fusion, preventing the entry of SARS-CoV into the cells. It may also exhibit an immune-modulating effect. Considering the mechanism of action, it is imperative to give hydroxychloroquine at the beginning of the infection ${ }^{1}$. Possible side effects of hydroxychloroquine include QT prolon- gation and retinal toxicity especially in patients with epilepsy, porphyria, myasthenia gravis, and glucose-6-phosphate dehydrogenase (G6PD) deficiency. Combined use of hydroxychloroquine with azithromycin is not recommended in children $^{7}$. Remdesivir is a nucleotide analogue which acts on viral RNA transcription after entering the cell. In adult studies, it seems to be safe and effective $^{37}$. Lopinavir-ritonavir combination is not considered in the treatment of children ${ }^{7}$. Drugs like remdesivir or lopinavir-ritonavir can be considered as compassionate treatment, after careful consideration of the risk-benefit ratio and technical issues ${ }^{38}$. Optimal dosing has not been established yet. Favipiravir is a drug which inhibits RNA polymerase without any dosing recommendation for children ${ }^{7}$. Whichever drug is used, antiviral therapy is not indicated in newborns in general ${ }^{1}$.

Cytokine storm syndrome, appears at the final stage of the disease and results frequently in extensive tissue damage, and multi-organ failure. The main mediator of this syndrome is interleukin-6 (IL-6). Therefore, IL-6 blockade or immunosupression with corticosteroids can be tried In order to neutralize this hyperinflammation ${ }^{39}$. However, current studies does not encourage the routine use of corticosteroids in COVID-1937. Tocilizumab is a recombinant humanized monoclonal antibody against IL-6 which binds to IL-6 receptor and blocks its function ${ }^{40}$.

Since ACE2 receptors play a crucial role in the development of the disease, recombinant ACE2 may be a treatment option for patients with severe COVID-19 (clinical trials.gov NCT04287686). Treatments like convalescent plasma and anakinra are still in the experimental phase.

In case of secondary bacterial infection, antibiotics may be prescribed. During autumn and winter seasons when influenza is prevalent, oseltamivir may be administrated. There is no role for standard immunglobulins or hormonal agents in the treatment of COVID-19. 
There are some reports on the association of vitamin D with COVID-19. Mortalities due to COVID19 are higher in cold climates and in higher latitutes. Vitamin D is known to reduce the production of proinflammatory cytokines, thus mitigating the cytokine storm in COVID-1941. However, due to lack of any solid evidence, routine administration of vitamin $D$ to the infected children is not recommended. However, if vitamin D levels are low in any children, it should be supplemented.

Discharge from the hospital is recommended when the body temperature remains normal for three consecutive days, respiratory symptoms are improved, and viral tests are negative ${ }^{42}$.

\section{Management of asymptomatic newborns}

All symptomatic or asymptomatic infants should have a complete blood count, C-Reactive Protein (CRP), and Real Time-PCR for SARS-CoV-2. If the infant has diarrhea or gastrointestinal symptoms, their feces may be analyzed. The infants should be isolated for at least 14 days. If considered stable, the infant may be discharged home, provided that $s /$ he is also kept isolated for 14 days ${ }^{1}$ In case the infant had been kept with other newborns in the same room, they should be tested for SARS-CoV-2 immediately and kept isolated until the PCR results are negative ${ }^{43}$. There is some evidence that asymptomatic individuals may also spread COVID-19. Therefore, healthcare staff dealing with such cases should wear PPE ${ }^{44}$.

\section{Management of symptomatic newborns}

Symptomatic infants should have chest radiography and/or chest CT in addition to the tests described above, including liver and kidney function tests and measurement of cardiac enzymes. In young infants, other respiratory viral pathogens may be investigated. These infants should be quarantined until their test results are negative. If SARS-CoV-2 is negative, the infant should be treated according to the other possible diseases. The healthcare staff should wear PPE1.
Discharge criteria for Infected infants may be as follows:

a. No fever for three consecutive days

b. Resolution of respiratory symptoms

c. Disappearance of radiological findings of the lung

d. Two nasopharyngeal swabs taken 24 hours apart yielding negative results ${ }^{45}$.

Currently there is no information on the long-term follow up of COVID-19 infection acquired in the neonatal period. Thus far, no fatalites have been reported.

\section{BREASTFEEDING}

Since breast milk contains a variety of immunoglobulins and other bioactive compounds, it is generally considered immune from viral infections. Breast milk of infected mothers may contain anti-SARS-CoV-2 antibodies. Until now, there are no reports indicating that breast milk contains the virus $\mathrm{RNA}^{46,47}$. If the mother is negative, it is safe to breastfeed the infant. Even if the mother is positive, she can still breastfeed her infant, despite some contradictory recommendations. Academy of Breastfeeding Medicine recommends breastfeeding after taking all possible precautions ${ }^{44}$. WHO also suggests that breastfeeding is safe in these infants, after maintaining all necessary precautions. Therefore, the mothers should be advised for breastfeeding by taking all precautions. However, if the infant and the mother are staying together, it should be kept in mind that airborne transmission can still occur. The mother should be advised not hug or kiss her infant. There should be at least 2 meters between the beds if the mother and the infant has to stay together. Centers for Disease Control (CDC) recommends that, if the mother has suspected or confirmed COVID-19 infection, the option of separate management of the mother and child should be considered as the first choice; the risks and the benefits of this separation and consequences of not starting, continuing or suspending breastfeeding should be shared 
with the family and documented ${ }^{48}$. If the mother is too sick to care for the newborn, or close contact is not preferred, the neonate will be managed separately and fed with freshly expressed breast milk. There is no need to pasteurize the expressed milk ${ }^{49}$. Expressed breast milk can be given to the infant by an uninfected family member. However, refraining from active breastfeeding may prevent bonding between the infant and the mother. The benefits of breastfeeding are superior to any risk of contamination by the virus. Suspending breastfeeding may have detrimental effects on the infant. Further data on the safety of breastfeeding are pending.

\section{VACCINATION DURING INFECTION}

All childhood vaccines should be given in accordance with the recommendations of the WHO or the Ministry of Health. COVID-19 is not a contraindication for vaccination or for deferral of vaccines. The prevalence of many childhood diseases have been reduced dramatically due to systematic vaccination of children. Any gap in this program may lead to a re-activation of these diseases, which might cost the lives of millions of children. BCG vaccination against tuberculosis may facilitate the maturation of $\mathrm{T}$ cells, and might offer some protection against viral infections, including COVID19 but there is no relevant evidence yet. It may be considered that multiple high-titre antibodies in the blood of children may also offer cross-protection against SARS-CoV-2 infection ${ }^{50}$. Even varicella, hepatitis, MMR or poliomyelitis vaccines have been proposed to protect and treat children with COVID-1951. Similarly, well-child care visits should not be deferred because of COVID-19 disease; growth and development of infants should be followed up regularly in accordance with the local guidelines.

\section{PSYCHOLOGICAL SUPPORT}

Unsolicited fear of infection should be dismissed, and correct scientific knowledge should be shared by the family and children. Education and shared decision making empowers the family. There is a wealth of information in the social media but they should be interpreted juditiously.

Some of the precautions taken by the governments are temporary lockdown and home confinement. The effects of closing schools and home confinement on children may be worrisome. Adverse effects may include longer screen time, irregular sleep, less healthy diets (i.e. eating too much and gaining weight), loss of peer interaction, and loss of cardiovascular fitness ${ }^{52}$. There are also major psychological drawbacks regarding children. Prolonged duration and fears of infection, frustration, boredom, inadequate flow of information, financial loss, and the lack of personal contact with peers, classmates, teachers, and family may confound the problem further. The risk of post-traumatic stress disorder is also increased almost four-fold ${ }^{53}$. Adherence to the changing style of education and dependence on technological resources may also induce some adaptation problems. These problems may be exaggerated in adolescents.

In economically disadvantaged families, children may be left unsupervised as parents have to go for work or have to look for other social welfare resources to survive. Some children may live in unsafe environments wherever safety could only be found at school ${ }^{54}$. The trauma of dealing with a seriously ill parent or death of a parent may be aggravated by the trauma of being forced to stay in foster care or other unwanted care institutions. If the newborn infant is separated from the mother, the mother and the whole family are exposed to anxiety and stress.

Treatment of psychological problems may become mainly symptomatic. Psychologists may provide online services to overcome such mental and psychological health issues. Social workers can also help families to overcome difficulties. Close and open communication with children is 
essential to identify psychological issues and relax children. Since parents are important role models for children, good parenting skills become more important for children who are forced to stay at home ${ }^{55}$. Relieving the panic and anxiety of children is important, which can be managed by accompanying children to daily household activities, and improving self-sufficiency skills. By allocating sufficient time to the patients and listening to them actively, pediatricians may also play a crucial role during this process. Physical and mental impacts of this pandemic on children should be kept minimal.

On the other hand, it is evident that health care staff working with COVID-19 cases may face various problems such as heavy work load, shortage of equipment, and poor prognosis of the patients. Therefore, health care staff also need psychological support ${ }^{1}$.

\section{CONCLUSION}

SARS-CoV-2 infection is a disease, that was declared recently as a pandemic, with many unknown issues. There is limited information on this previously unknown disease. With ongoing scientific research, its pathophysiology and management options may change. Children should be included in clinical trials on the characteristics of the disease, serosurveys, transmissibility studies, and vaccine trials. Otherwise, a great opportunity will be lost to obtain knowledge to guide treatment of children. Evidence on vertical transmission of the virus and clinical manifestations in the newborns is expected to mount every other day. There is a growing body of evidence on the subject, and continuous updates are important to implement current knowledge in the management of COVID19 in infants and other children.

\section{REFERENCES}

1. Ovalı F. SARS-CoV infection and the newborn. Front Pediatr. 2020;8:294. [CrossRef]

2. Chowel G, Abdirizak F, Lee S et al. Transmission charc- teristics of MERS and SARS in the healthcare setting: a comparative study. BMC Med. 2015;13:210. [CrossRef]

3. Worldometer coronavirus. https://www.worldometers. info/coronavirus/\#countries Accessed on May 20, 2020.

4. Ludvigsson J. Systematic review of COVID-19 in children shows milder cases and a better prognosis than adults. Acta Pediatr. 2020;109:1088-95. [CrossRef]

5. Tagarro A, Epalza C, Santos M, et al. Screening and Severity of Coronavirus Disease 2019 (COVID-19) in Children in Madrid, Spain. JAMA Pediatr. 2020;e201346. [CrossRef]

6. CDC COVID-19 Response Team. Coronavirus Disease 2019 in Children - United States, February 12-April 2, 2020. MMWR Morb Mortal Wkly Rep. 2020;69:422-6. [CrossRef]

7. Tezer H, Bedir Demirag T. Novel coronavirus disease in children. Turk J Med Sci. 2020;50:592-603. [CrossRef]

8. Wu Z, McGoogan JM. Characteristics of and Important Lessons From the Coronavirus Disease 2019 (COVID-19) Outbreak in China: Summary of a Report of 72314 Cases From the Chinese Center for Disease Control and Prevention. JAMA. 2020. [CrossRef]

9. Feng F, Xiaoping L. Facing the pandemic of 2019 novel coronavirus infections: the pediatric perspectives. Chin J Pediatr. 2020;58:81-5.

10. Jiatong $\mathrm{S}$, Wenjun L. Epidemiological characteristics and prevention and control measures of Corona Virus Disease 2019 in children. J Trop Med. 2020;20:153-6.

11. DongY,MoX, HuY, etal. EpidemiologyofCOVID-19among children in china. Pediatrics. 2020;145(6):e20200702. [CrossRef]

12. Hamming I, Timens W, Bulthuis ML, Lely AT, Navis G, van Goor H. Tissue distribution of ACE2 protein, the functional receptor for SARS coronavirus. A first step in understanding SARS pathogenesis. J Pathol. 2004;203:631-7. [CrossRef]

13. Ciaglia E, Vecchione C, Puca AA. COVID-19 infection and circulating ACE2 levels: protective role in women and children. Front Pediatr. 2020;8:206. [CrossRef]

14. Li M, Yao D, Zeng X, et al. Age related human T cell subset evolution and senescence. Immun Ageing. 2019;16:24. [CrossRef]

15. Liu L, Wei $Q$, Lin $Q$, et al. Anti-spike IgG causes severe acute lung injury by skewing macrophage responses during acute SARS-CoV infection. JCI Insight. 2019;4:e123158. [CrossRef]

16. Rawat $M$, Chandrasekharan P, Hicar MD, Lakshminrusimha S. COVID-19 in Newborns and Infants-Low Risk of Severe Disease: Silver Lining or Dark Cloud? Am J Perinatology. 2020;37(8):845. [CrossRef]

17. Chan JF, Yuan S, Kok KH, et al. A familial cluster of pneumonia associated with the 2019 novel coronavirus indicating person-toperson transmission: a study of a family cluster. Lancet. 2020;395(10223):514-23. [CrossRef]

18. Qiu H, Wu J, Hong L, Luo Y, Song Q, Chen D. Clinical and epidemiological features of 36 children with coronavirus disease 2019 (COVID-19) in Zhejiang, China: an observational cohort study. Lancet Infect Dis. 2020;20:689-96. [CrossRef]

19. Passanisi S, Lombardo F, Salzano G, Pajno GB. Are Children Most of the Submerged Part of SARS-CoV-2 Ice- 
berg? Frontiers in Pediatrics. 2020;8:213. [CrossRef]

20. Wang W, Xu Y, Gao R, et al. Detection of SARS-CoV-2 in Different Types of Clinical Specimens. JAMA. 2020;323:1843-4. [CrossRef]

21. Chen H, Guo J, Wang C, et al. Clinical characteristics and intrauterine vertical transmission potential of COVID-19 infection in nine pregnant women: a retrospective review of medical records. Lancet. 2020;395(10226):80915. [CrossRef]

22. Jing Y, Run-Qian L, Hao-Ran W, et al. Potential influence of COVID-19/ACE2 on the female reproductive system. Mol Hum Reprod. 2020;26:367-73. [CrossRef]

23. Ferrazzi E, Frigerio L, Savasi V, et al. Vaginal delivery in SARS-CoV-2-infected pregnant women in Northern Italy: a retrospective analysis. BJOG. 2020. [CrossRef]

24. Lu X, Zhang L, Du H, et al. SARS-CoV-2 infection in children. N Engl J Med. 2020;382:1663-5. [CrossRef]

25. Lauer SA, Grantz KH, Bi Q, et al. The Incubation Period of Coronavirus Disease 2019 (COVID-19) From Publicly Reported Confirmed Cases: Estimation and Application. Ann Intern Med. 2020;172:577-82. [CrossRef]

26. Zheng F, Liao C, Fan QH et al. Clinical characteristics of children with Coronavirus Disease 2019 in Huei, China. Curr Med Sci. 2020;40:275-80. [CrossRef]

27. Bialek S, Boundy E, Bowen V, et al. Severe outcomes among patients with coronavirus disease 2019 (COVID19) - United States, February 12-March 16, 2020. MMWR. 2020;69:343-6. [CrossRef]

28. Chen Z, Fu J, Shu Q Chen Y, Hua C et al. Diagnosis and treatment recommendations for pediatric respiratory infection caused by the 2019 novel coronavirus. World Journal of Pediatrics. 2020;49:139-46. [CrossRef]

29. Rasmussen SA, Thompson LA. Coronavirus Disease 2019 and Children: What Pediatric Health Care Clinicians Need to Know. JAMA Pediatr. 2020. [CrossRef]

30. Zhang Y. The Epidemiological Characteristics of an Outbreak of 2019 Novel Coronavirus Diseases (COVID-19) - China, 2020. Chinese Journal of Epidemiology (by The Novel Coronavirus Pneumonia Emergency Response Epidemiology Team). Zhonghua Liu Xing Bing Xue Za Zhi 2020;41:145-51 (Abstract) (Article in Chinese)

31. L'Huillier AG, Brito F, Wagner $\mathrm{N}$ et al. Identification of viral signatures using high throughput sequencing onblood of patients with Kawasaki Disease. Frontiers Pediatr. 2019;7:524. [CrossRef]

32. Verdoni L, Mazza A, Gervasoni A, et al. An outbreak of severe Kawasaki-like disease at the Italian epicentre of the SARS-CoV-2 epidemic: an observational cohort study. Lancet. 2020;395(10239):1771-8. [CrossRef]

33. Jones VG, Mills M, Suarez D, et al. COVID-19 and Kawasaki Disease: Novel Virus and Novel Case. Hosp Pediatr. 2020;10:537-40. [CrossRef]

34. Royal College of Paediatrics and Child Health GuidancePaediatrics multisystem inflammatory syndrome temporally associated with COVID-19. 2020 https://rcpch. ac.uk/resources/guidance-paediatric-multisystem-inflammatory-syndrome-temporally-associated-covid-19 (May 5, 2020).

35. Shek CC, Ng PC, Fung GP, et al. Infants born to mothers with severe acute respiratory syndrome. Pediatrics. 2003; 112:e254. [CrossRef]
36. Cai JH, Wang XS, Ge YL et al. First case of 2019 novel coronavirus infection in children in Shanghai. Chin J Pediatr. 2020;58:E002. [CrossRef]

37. de Wit E, Feldmann F, Cronin J, et al. Prophylactic and therapeutic remdesivir (GS-5734) treatment in the rhesus macaque model of MERS-CoV infection. Proc Natl Acad Sci U S A. 2020;117:6771-6. [CrossRef]

38. De Luca D. Managing neonates with respiratory failure due to SARS-CoV-2. Lancet Child Adolesc Health. 2020;4:e8. [CrossRef]

39. Veronese N, Demurtas J, Yang L, et al. Use of Corticosteroids in Coronavirus Disease 2019 Pneumonia: A Systematic Review of the Literature. Front Med (Lausanne). 2020;7:170. [CrossRef]

40. Biggioggero M, Crotti C, Becciolini A, Favalli EG. Tocilizumab in the treatment of rheumatoid arthritis: an evidence-based review and patient selection. Drug Des Devel Ther. 2018;13:57-70. [CrossRef]

41. Molloy EJ, Murphy N. Vitamin D, Covid-19 and children. Ir J Med 2020;113:59-61.

42. Shen K, Yang Y, Wang T, et al. Diagnosis, treatment, and prevention of 2019 novel coronavirus infection in children: experts' consensus statement. World J Pediatr. 2020;16:223-31. [CrossRef]

43. Wang J, Qi H, Bao L, Li F, Shi Y. National Clinical Research Center for Child Health and Disorders and Pediatric Committee of Medical Association of Chinese People's Liberation Army. A contingency plan for the management of the 2019 novel coronavirus outbreak in neonatal intensive care units. Lancet Child Adolesc Health. 2020;4:258-9. [CrossRef]

44. Centers for Disease Control and Prevention (CDC). Interim Infection Prevention and Control Recommendations for Patients with Suspected or Confirmed Coronavirus Disease 2019 (COVID- 19) in Healthcare Settings March 10, 2020. https: //www.cdc.gov coronavir s/2019-ncov/ infection-control/contr ol-recommendations.html. Accessed March 17, 2020.

45. American Academy of Pediatrics. https://services.aap. org/en/pages/2019-novel-coronavirus-covid-19-infections/ Accessed on 10 April 2020.

46. Academy of Breastfeeding Medicine Statement on coronavirus 2019 (COVID-19). Academy of Breastfeeding Medicine. (2020) Available at https://www.bfmed.org/ abm-statemnt-coronavirus. 20.03.2020.

47. Centers for Disease Control. Available at https://www. cdc.gov/coronavirus/2019-ncov/prepare/pregnancybreastfeeding. Accessed: 21.03.2020.

48. Centers for Disease Control and Prevention. https:// www.cdc.gov/coronavirus/2019-ncov/specific-groups/ pregnancy-guidance-breastfeeding.html

49. Union of European Neonatal and Perinatal Societies. Breastfeeding and SARS-CoV İnfection. 28 February 2020 https://www.uenps.eu/2020/03/16/sars-cov-2infection-sin-recommendations-endorsed-by-uenps/Accessed: 24 March 2020.

50. Zimmermann P, Curtis N. Coronavirus infections in children including COVID-19: an overview of the epidemiology, clinical features, diagnosis, treatment and prevention options in children. Pediatr Infect Dis J. 2020;39:355-68. [CrossRef] 
51. Salman S, Salem MS. Routine childhood immunization may protect against COVID-19. Med Hypothesis. 2020;140:109689. [CrossRef]

52. Wang G, Zhang Y, Zhao J, Zhang J, \& Jiang F. Mitigate the effects of home confinement on children during the COVID-19 outbreak. The Lancet. 2020;395(10228):945-7. [CrossRef]

53. Sprang G, Silman M. Posttraumatic stress disorder in parents and youth after health-related disasters. Disaster Med Public Health Prep. 2013;7:105-10. [CrossRef]
54. Haward MF, Moore GP, Lantos J, Janvier A. Pediatric ethical issues during the COVID-19 pandemic are not just about ventilator triage. Acta Paediatrica. 2020;109(8):1519-21. [CrossRef]

55. Wang G, Zhang Y, Zhao J, Zhang J, \& Jiang F. Mitigate the effects of home confinement on children during the COVID-19 outbreak. The Lancet. 2020;395(10228):945-7. [CrossRef] 